\title{
"HINDUISM" AND THE HISTORY OF "RELIGION": PROTESTANT PRESUPPOSITIONS IN THE CRITIQUE OF THE GONGEPT OF HINDUISM
}

\author{
Will SweEtman
}

The claim that Hinduism is not a religion, or not a single religion, is so often repeated that it might be considered an axiom of research into the religious beliefs and practices of the Hindus, were it not typically ignored immediately after having been stated. The arguments for this claim in the work of several representative scholars are examined in order to show that they depend, implicitly or explicitly, upon a notion of religion which is too much influenced by Christian conceptions of what a religion is, a conception which, if it has not already been discarded by scholars of religion, certainly ought to be. Even where such Christian models are explicitly disavowed, the claim that Hinduism is not a religion can be shown to depend upon a particular religious conception of the nature of the world and our possible knowledge of it, which scholars of religion cannot share.

Two claims which I take to have been established by recent work on the history of the concept "religion" provide the starting point for my argument here. The first is that, while the concept emerged from a culture which was still shaped by its Christian history, nevertheless the establishment of the modern sense of the term was the result of "a process of extracting the word from its Christian overtones" (Bossy 1982: 12). ${ }^{1}$ The second is that the concept, like all abstractions, implies a categorization of phenomena which is imposed upon rather than emergent from them: "religion" is not a natural kind. It has been suggested that the rejection by some scholars of the second claim is evidence that the term, and the discipline for which it serves as the central organizing concept, has not yet fully completed the process of disengagement from Christian theological presuppositions. Thus Timothy Fitzgerald writes:

Religion is really the basis of a modern form of theology, which I will call liberal ecumenical theology, but some attempt has been made to

\footnotetext{
${ }^{1}$ Bossy refers not only to the term "religion" but also "society", noting that "the history of the word 'society' ... is practically identical with the history of the word 'religion", and several other terms including "state, property, philosophy, charity, communion, conversation" (1982: 12).
} 
disguise this fact by claiming that religion is a natural and/or a supernatural reality in the nature of things that all human individuals have a capacity for, regardless of their cultural context. This attempt to disguise the theological essence of the category and to present it as though it were a unique human reality irreducible to either theology or sociology suggests that it possesses some ideological function ... that is not fully acknowledged. (Fitzgerald 2000a: $4-5)^{2}$

Fitzgerald gives a number of arguments for this claim and for his further proposal that scholars who do not have a theological agenda ought to prefer terms which offer greater analytical precision than "religion". One such argument considers several works by religionists and anthropologists on Hinduism in order to show that "religion" fails to pick out anything that can be analytically separated from other institutionalized aspects of Indian culture, that "the category religion does not effectively demarcate any institutions located in a putatively non-religious domain such as Indian society", in short, that "Hinduism is not a "religion" (Fitzgerald 2000a: chap. 7; see also Fitzgerald 1990 and 2000b). The claim is significant and is found in the work of several other scholars. ${ }^{3}$ While agreeing with much of Fitzgerald's analysis - specifically that religion is not "in the nature of things" or a reality irreducible by other forms of analysis, and that the study of religion continues to be too much influenced by unacknowledged Christian theological presuppositions - I will argue that it is precisely the claim that Hinduism is not a religion which reveals lingering Christian and theological influence even in the works of

\footnotetext{
${ }^{2}$ Elsewhere Fitzgerald writes: "What I am arguing is that theology and what is at present called religious studies ought to be two logically separate levels of intellectual activity, but that in actual fact the latter is conceptually and institutionally dominated by the former. This domination is disguised because it is embedded in our a priori central analytical category, and abandoning that category altogether appears, even to scholars who are themselves critically aware of the legacy of phenomenology, to be throwing the baby out with the bathwater" (1997: 97). In more general terms, others have suggested that the claim that religion is a sui generis phenomenon is associated with an approach to the study of religion which tends to assume the truth of religion. So Russell McCutcheon notes that "one aspect of the discourse on sui generis religion" is a "theoretically undefended preference for sympathetic and descriptive insiders' accounts" and that the "the dominant yet uncritical and theoretically undefendable conception of religion as sui generis effectively precludes other more sociopolitically and historically sensitive methods and theories" (1997: 122-123). Likewise, the belief that religion, because irreducible to anything else, is best explained "on its own terms" is described by Samuel Preus as "the last bastion of theology" (1987: xvi).

${ }^{3}$ See, in addition to those discussed below, Smith 1987: 34; Hardy 1990: 145; Oberoi 1994: 17; Dalmia and Stietencron 1995: 20; Larson 1995: 31; Frykenberg 1997: 82.
} 
those who explicitly disclaim such influence. Such influence exists on two levels, the first relatively superficial, the other more profound. The first level will be demonstrated in three authors-R. N. Dandekar, Heinrich von Stietencron, and S. N. Balagangadharawho implicitly or explicitly model the concept of religion on Christianity. This model is disclaimed by two further authors, Frits Staal and Timothy Fitzgerald, but their arguments against the description of Hinduism as a religion, I will argue, nevertheless depend upon a Protestant Christian epistemology.

\section{Religion as implicitly modeled upon Christianity}

In his chapter on Hinduism for the Handbook for the History of Religions, a quasi-official document for the International Association for the History of Religions, R. N. Dandekar argues that

Hinduism can hardly be called a religion at all in the popularly understood sense of the term. Unlike most religions, Hinduism does not regard the concept of god as being central to it. Hinduism is not a system of theology - it does not make any dogmatic affirmation regarding the nature of god ... . Similarly, Hinduism does not venerate any particular person as its sole prophet or as its founder. It does not also recognize any particular book as its absolutely authoritative scripture. Further, Hinduism does not insist on any particular religious practice as being obligatory, nor does it accept any doctrine as its dogma. Hinduism can also not be identified with a specific moral code. Hinduism, as a religion, does not convey any definite or unitary idea. There is no dogma or practice which can be said to be either universal or essential to Hinduism as a whole. Indeed, those who call themselves Hindus may not necessarily have much in common as regards faith or worship. What is essential for one section of the Hindu community may not be necessarily so for another. And, yet, Hinduism has persisted through centuries as a distinct religious entity. (Dandekar 1971: 237)

The centrality of the concept of god, the veneration of a particular person as the founder of a religion, and the recognition of a particular book as an absolutely authoritative scripture are characteristic of certain religions (Christianity and Islam in particular). Dandekar extrapolates from these characteristics and implicitly defines the "popularly understood sense of the term" religion as including these three characteristics. Had he explicitly defined "religion" in this way, it is likely that his definition would have been attacked as being too narrow and, in particular, as too much influenced by particular religions, 
especially certain forms of Christianity. Nevertheless, what Dandekar's comments amount to is the claim that Hinduism is not like Christianity, or perhaps that Hinduism is not the same sort of religion that Christianity is. This claim is unobjectionable, but is nevertheless quite different from the claim that Hinduism is not a religion. Dandekar refers only to the "popularly understood sense of the term [religion]" and this allows him to conclude that "Hinduism has persisted through centuries as a distinct religious entity". Other writers, including S. N. Balagangadhara - who, significantly, misreads Dandekar as referring to the "properly understood sense" of religion (1994: 15) - draw more radical conclusions from structurally similar arguments.

One such is Heinrich von Stietencron, who argues that Hinduism refers not to one religion but, rather, should be taken "to denote a socio-cultural unit or civilization which contains a plurality of distinct religions" (1997: 33). The idea that Hinduism is a religion derives, he suggests, from a fundamental misunderstanding of the term "Hindu", which was originally a Persian term denoting "Indians in general" (Stietencron 1997: 33). Following the permanent settlement of Muslims in India, Persian authors began to use the term to refer to Indians other than Muslims and identified several different religions among the Hindus. However, Stietencron argues that

when Europeans started to use the term Hindoo, they applied it to the non-Muslim masses of India without those scholarly differentiations. Most people failed to realise that the term "Hindu" corresponded exactly to their own word "Indian" which is derived, like the name "India", from the same Indus river, the indos of the Greek. The Hindu, they knew, was distinct from the Muslim, the Jew, the Christian, the Parsee and the Jain who were all present in the Indian coastal area known to western trade. Therefore they took the term "Hindu" to designate the follower of a particular Indian religion. This was a fundamental misunderstanding of the term. And from Hindu the term "Hinduism" was derived by way of abstraction, denoting an imagined religion of the vast majority of the population - something that had never existed as a "religion" (in the Western sense) in the consciousness of the Indian people themselves. (Stietencron 1997: 33-34, emphasis added) ${ }^{4}$

4 This brief history of European usage of "Hindu" or "Hindoo" and "Hinduism" is vastly oversimplified and represents Stietencron's attempt to reconstruct what might have happened rather than being based on examination of the relevant texts. A more detailed, but still inadequate, account of the same process is given by Stietencron in two other articles $(1988,1995)$. John Marshall, in India from 1668 to 1677 knew that "the name Hindoo" was primarily a geographical, not a religious 
Given that, as several writers have recently shown, the modern sense of "religion" as a reified entity in which other people are involved only began to develop in the West from the sixteenth century, it would hardly be surprising were such a concept not to be present in the consciousness of the Indian people prior to its articulation in the West. ${ }^{5}$ Like Dandekar, Stietencron does not make explicit here what he means by "the Western sense" of religion. ${ }^{6}$ We can gain some idea of what sense he intends by examining the counts on which Hinduism is said to fail to be a religion. Hinduism fails to be a religion for Stietencron because "[t]here is hardly a single important teaching in 'Hinduism' which can be shown to be valid for all Hindus, much less a comprehensive set of teachings" (1997: 36). Here Stietencron perpetuates the idea, which he attributes to Christians, that doctrinal uniformity is the sine qua non of a religion: because Hinduism does not insist on doctrinal uniformity, it is not a religion. If this is what Stietencron means by saying that Hinduism "never existed as a 'religion' (in the Western sense)", then what his claim amounts to is that Hinduism is not, or is not like, Christianity. This

concept (Marshall 1927: 182) and Stietencron acknowledges that "the correct derivation (from the river) was current in Europe before 1768" (1997: 50). Accounts of Hinduism by the more scholarly of the early European writers were at least as sophisticated as the earlier Persian accounts with respect to distinguishing groups within Hinduism. The same may not have been true for travelers' tales, but it is hardly appropriate to compare these with the works of the outstanding Persian scholars Stietencron mentions (Abū-l Qāsim, al-Masūdī, al-Idrī̄ī and Shahrastānī). In the seventeenth century Roberto Nobili explicitly acknowledged a plurality of religions among Hindus, while at the start of the eighteenth century Bartholomäus Ziegenbalg noted that the Indians "have forged many different religions" noting that, in addition to the two main religions Śaivism and Vaiṣnavism, the Jains and the Buddhists were regarded as separate, heterodox religious groups. For a more detailed account of these authors and critique of Stietencron's discussion of them see Sweetman (2001). Lorenzen similarly critiques Stietencron's oversimplification of the history of this term, noting that he "quite blithely jumps from the sixth century B.C. to the nineteenth century A.D. with virtually no discussion whatever of the intervening uses of the term 'Hindu' either by foreigners or native Indians" (Lorenzen 1999: $635)$.

5 This is not to say that such an understanding of religion could not have developed independently of Western influence, as Michael Pye has suggested in his discussion of the eighteenth-century Japanese thinker Tominaga Nakamoto (1992: 27-28; see also Pye 2003). And, indeed, there is evidence of a reified understanding of religion in India in some circumstances. See O’Connell 1973; Wagle 1997; Lorenzen 1999; Sharma 2002.

${ }^{6}$ Although he does write that "the term religion ... can only be applied to corporately shared coherent systems of world explanation and values" (Stietencron 1997: 45, original emphasis). 
much is not to be contested. ${ }^{7}$ It does not follow that because Hinduism is not like Christianity, it is not a religion, unless religion be defined on an explicitly Christian model. Stietencron in fact comes close to this as an ostensive definition of religion when he writes that "[i]f we accept Judaism, Christianity and Islam as 'religion' ... we cannot avoid concluding that there are a number of different 'religions' existing side by side within 'Hinduism"' (1997: 41). He goes on to propose that we should describe Vedic religion, Advaita Vedānta, Vaiṣnavism, Śaivism, and Śaktism (among others) as independent religions within the socio-cultural unit called Hinduism. ${ }^{8}$ Once again, the reasons for thinking of Advaita Vedānta, Vaiṣnavism, or Śaivism as independent religions are because they resemble Christianity.

[E]ach of these religions possesses its own set of revealed holy scriptures recognized by all its members, each worships the same god as the highest deity, (or reverts to an impersonal Absolute as the highest principle, or recognizes a particular pantheon). Each of the literate Hindu religions has its own clearly identifiable and often immensely extensive theological literature, each knows its great saints, its major reformers, and the founders of sects. (Stietencron 1997: 44)

Stietencron admits: "No doubt, some of the Hindu religions are closely related to one another" but insists that, like Judaism, Christianity and Islam, "they are different religions". That which establishes difference in apparently similar forms of religion is "the authoritative religious tradition received and perpetuated by a wider community ... . Difference between religions is, therefore, a result of decisive variance in the authoritative traditions or belief systems" (Stietencron 1997: 41-42). Again, we may see here the influence of a Protestant Christian insistence on belief as the final divider of religious communities.

Stietencron's proposal raises three questions of identity and authority: Who constitutes the community that receives and perpetuates authoritative religious tradition? Who decides when variance becomes "decisive"? Who arbitrates what is and what is not "authoritative tradition"? The difficulty in answering these questions reveals the arbitrary nature of Stietencron's willingness to describe

\footnotetext{
${ }^{7}$ Although it is also arguable that, despite some claims to the contrary, historically Christianity itself has not been characterized by doctrinal uniformity.

${ }^{8}$ An alternative view of these traditions as parts of a single, polycentric Hinduism has been advanced by Julius Lipner (1994, 1996).
} 
Vaiṣnavism, but not Hinduism, as a religion. All Stietencron is able to say is that a "certain margin of tolerance usually allows for sectarian differentiation in doctrine and practice. Yet there are limits, unseen thresholds. Overstepping them leads to segregation or expulsion and, if there are enough followers, to forming a new religious unit" (1997: 42). This is not to say that it is never appropriate to consider Vaiṣnavism, Śaivism, and Śaktism as separate religions, merely that it is not the case that they, in contrast to Hinduism, "really" are separate religions. In another article in which he argues for conceiving the several forms of Hinduism as independent religions, Stietencron states that

[n]one of these Hindu religions - except perhaps for monastic Advaita Vedānta - developed an all-India institutional body invested with the power to pass binding judgments on the correct exegesis of sacred scriptures. Diverging interpretations of religious tradition could not be effectively banned. Authority was never vested in a central organization comparable to the Roman church. (Stietencron 1995: 71)

Such a body presumably would be able to rule on what constitutes "authoritative religious tradition", and what constitutes "decisive variance". Again, however, Hinduism appears not to be a religion because it lacks something definitive of certain forms of Christianity.

\section{Religion as explicitly modelled upon Christianity}

The claim that Hinduism is not a religion has been argued most vehemently and at greatest length by S. N. Balagangadhara (1994). For Balagangadhara, the "Hinduism" discussed by European scholars is "an imaginary entity" (1994: 116, 298), a creation of European scholars, as are the other world religions supposed to have emerged from India:

The creation of Hinduism antedates that of Buddhism. By this, I do not imply that Hinduism existed in India before Buddhism came into being - this claim, after all, is a standard text-book trivium - but that the Europeans created Buddhism after they had created Hinduism. (Balagangadhara 1994: 138)

Balagangadhara gives several independent arguments and several versions of his thesis. The strongest is that not only is Hinduism not a religion, but that it is impossible that Hinduism could be a religion: "no matter what the facts are, there could simply be no 'religion' in 
India" (Balagangadhara 1994: 394). His argument for this claim depends on his definition of a religion as "an explanatorily intelligible account of the Cosmos and itself" and he concludes that "Indian traditions could not possibly be religions because the issue of the origin of the world cannot properly be raised there" (1994: 384, 398). His argument for this strong version of his thesis will be considered briefly below; however, in his other arguments for a weaker version of his thesis, Balagangadhara makes explicit what I have argued is implicit in several other authors who argue that Hinduism is not a religion, and it is therefore this part of his work that I will consider here.

Balagangadhara expresses the problem thus:

Consider just what is being asked of us. The Hindus, the AmericanIndians, and the Greeks have (had) a set of traditions that lack the following: (i) creeds, (ii) beliefs in God; (iii) scriptures; (iv) churches. Despite this, these traditions are not only 'religions', but are also distinguishable from each other as religious traditions. (Balagangadhara 1994: 22-23)

He argues, however, that precisely these properties are "what makes Judaism, Christianity and Islam into religions", for if "we bracket away creeds, beliefs in God and prophets, existence of scriptures and churches from Judaism, Christianity and Islam ... we could not even tell the difference between these traditions, let alone distinguish them from Hinduism or Greek religion or whatever else. We would get an amorphous whole that could not even be called a religion" (Balagangadhara 1994: 23-24). Balagangadhara sums up his argument in the following dilemma:

Some set of properties are absolutely necessary for some traditions (Judaism, Christianity, Islam) to be religions. But if one accepts this, the threat is that other cultures appear not to have religions at all. For some reason or another, other cultures are said to have religions too. However, the conditions under which other cultures are to have religion are precisely those that make it impossible for the Semitic religions to be religions. That is to say, if the Semitic religions are what religions are other cultures do not have religions. If other cultures have religions, then the Semitic religions are not religions. The inconsistency lies in insisting that both statements are true. (Balagangadhara 1994: 24-25, emphasis added)

The crucial premise in this argument is the assumption that "the Semitic religions are what religions are"; that is, rather than merely being examples of religion, they are "exemplary instances, i.e. prototypical 
examples of the category religion" (Balagangadhara 1994: 301, original emphasis).

Balagangadhara justifies his choice of these religions as exemplary instances by arguing that when "investigating that which is designated by the term "religion"” we ought to start with cultures and languages where the term already exists, because "to pick out entities as prototypical instances of the term from other cultures and languages where the term 'religion' itself does not exist is to take an epistemic decision. That is, one already assumes beforehand that objects from other cultures instantiate the term as well. Such a decision is not justifiable at this stage" (1994: 304-305), i.e., at the start of an investigation into that to which the term "religion" refers. Although the modern concept of religion first gained wide currency in the West, it emerged against the background of a growing detachment from Christianity rather than as a part of Christianity's uncontested self-description (see Bossy 1982: 12; Preus 1987: xiv). ${ }^{9}$ This important gloss is missing in Balagangadhara's argument. The academic study of the religions is not, in the words of Vivek Dhareshwar (discussing Balagangadhara), "condemned to be Christian" (Dhareshwar 1996: 130). ${ }^{10}$

Conceding that applying this argument to Judaism and Islam may generate problems, Balagangadhara limits his claim of prototypicality to Christianity: "Whether Judaism and Islam are religions or not, at the least, our term picks out Christianity as one. When we use the category 'religion', we minimally refer to Christianity" (Balagangadhara 1994: 305). If one denies this, and argues that "Christianity is not an exemplary instance of 'religion', then we have no other examples of religion" (Balagangadhara 1994: 307). Balagangadhara's argument, then, has the following form:

First premise: Christianity is prototypically what religion is.

Second premise: Hinduism does not share all (or perhaps any) of the relevant properties of Christianity.

Conclusion: Hinduism is not a religion.

9 Balagangadhara's second reason for choosing the Semitic religions as prototypical instances of religion is that "[e]ach of the three traditions has described itself as a religion" (1994: 305). As Wilfred Cantwell Smith (1991 [1962]) has shown, each has also denied the appropriateness of being so described.

${ }^{10}$ In the same volume both Philip Almond (1996: 140) and David Loy (1996: 151152) note that Balagangadhara emphasizes too much the formative influence of Christianity on modern European thought. 
The first premise, as Balagangadhara expresses it, is problematic, or at least ambiguous. However, the argument is only valid if he means something like the set of properties of Christianity is identical with the set of properties of (a) religion. I have argued that this argument is implicit in those authors who argue that Hinduism is not a religion because it lacks a founder, a single authoritative text, or some other specified characteristic. The concept of religion invoked in these arguments is plainly too narrow, and too much influenced by Christianity. If such a concept has not already been abandoned by the academic study of religions - and reasons can be given for thinking that the process of doing so has started, even if it is not completethen it certainly ought to be. ${ }^{11}$

Balagangadhara declares himself tempted to say that "because some properties characteristic of Christianity are absent from traditions elsewhere (like, say, in 'Hinduism' or 'Buddhism'), the latter cannot possibly be religions". This position is justified, he writes, "only if one is able to show that the properties of Christianity which one has identified are also the properties of religion" (Balagangadhara 1994: 309). His first premise must be making a claim like this in order for his argument to be valid. But the section of his book in which this statement appears is entitled "Thou shalt resist temptation..." and Balagangadhara refrains from saying that the sort of characteristics he has been discussing (creeds, beliefs, scriptures, churches) are the relevant properties of Christianity, i.e., those that make it a religion and the lack of which make Hinduism something other than a religion. He states: "I am not defining explicitly what the concept 'religion' means; I am simply identifying an example, a prototypical example of the category religion" (Balagangadhara 1994: 307). He has not yet answered the question "What makes Christianity a religion?" (Balagangadhara 1994: 317). His answer, when it comes, is that "religion is an explanatorily intelligible account of both the Cosmos and itself" (Balagangadhara 1994: 384; his argument for this definition is given in pages 331-334). Because the "configuration of learning" in Asian cultures is performative, rather than theoretical, such accounts

\footnotetext{
${ }^{11}$ Lawson and McCauley detect a theological bias in " $[\mathrm{t}]$ he insistence in the study of religion that texts and traditions are critical features of full-fledged religions" which, they argue, "has always served as a strategy for insulating the 'great' world religions generally and Christianity in particular from the sort of analyses otherwise reserved for 'primitives' — which is to say, all the rest of humanity" (1990: 6).
} 
are "absent from the cultures of Asia" (Balagangadhara 1994: 314), and hence Asia has ritual (performative) but not religious traditions. The argument is formally valid, but we have as little reason to accept Balagangadhara's restriction of religion to explanatorily intelligible accounts of the cosmos - of a type Hinduism allegedly cannot giveas we would to accept a definition of religion as necessarily involving creeds, beliefs, scriptures, and churches. While Balagangadhara's definition is explicitly modelled upon Christianity, Philip Almond argues that even what Balagangadhara takes as "as essentially or prototypically Christian" - and hence prototypically religious - is in fact "only one particular manifestation of [Christianity], namely and crudely put, an Enlightenment deistic Christianity" (Almond 1996: 144) and, thus, that for most of its history Europe too would have lacked religions. In Balagangadhara's work can be clearly seen the form of the argument that underlies the claims of other authors that Hinduism is not a religion. It is equally clear that this argument depends on a tendentious concept of religion. Balagangadhara himself acknowledges that "there is a quasi-universal consensus that the 'Western' concept of religion is inadequate" (Balagangadhara 1994: 313) but he fails to see that this in itself is not a reason for thinking that Hinduism is not a religion but, rather, a reason to work out a better concept of religion.

\section{Religion, ritual and the real}

While Frits Staal follows Balagangadhara in emphasizing the importance of ritual in Asian religion and in arguing that "the idea of religion is essentially a Western concept, inspired by the three monotheistic religions of the West ... not applicable to the phenomena we find in and around the Himalayas" (Staal 1982: 39), unlike Balagangadhara he does consider attempts to formulate wider conceptions of religion. Nevertheless, in his argument he does at times slip back into a position formally similar to that of Balagangadhara and the other authors discussed above. More significantly he also depends upon an epistemological ideal which is arguably still more profoundly influenced by Protestant Christian thought, and which, it will be argued, is shared by Fitzgerald.

Discussing what he calls "religion' in its fullest sense", Staal writes: "Doctrines and beliefs are regarded as religious when they involve 
belief in a god or gods, in paradise and hell, salvation, and similar religious concepts that are characteristic of the three monotheistic religions of the West" (Staal 1989: 389). ${ }^{12}$ He makes the point that

most of the other 'religions' of mankind are deficient in one or another respect when studied within this perspective .... The main reason, however, that Asian traditions do not fit the Western pattern of religion is that their emphasis is not on doctrines or beliefs, but on ritual, mysticism or both. In so far as doctrines or beliefs are mentioned at all, they are not primary but added: they are of the nature of secondary interpretations, often rationalizations and generally after-thoughts. (Staal 1989: 389-390, emphasis added)

There are certainly counter-examples to Staal's characterisation of Asian traditions. It would be difficult, for example, to describe Rāmānuja's project as a secondary interpretation, a rationalization or an after-thought. Nevertheless Staal asserts:

Hinduism does not merely fail to be a religion; it is not even a meaningful unit of discourse. There is no way to abstract a meaningful unitary notion of Hinduism from the Indian phenomena, unless it is done by exclusion, following the well-worn formula: a Hindu is an Indian who is not a Jaina, Buddhist, Parsi, Christian, Muslim, Sikh, Animist ... (the list is indefinite). When faced with such data, should we abandon the concept of religion altogether? Basically, there are two possible procedures. We can either start with a rather narrow concept of "religion", based upon the three Western monotheisms, and see to what extent such a concept of religion can be used in Asia. Or else we can try to formulate a wider and more flexible concept, and see just where that leads us. (Staal 1989: 397)

Staal suggests that the concept of religion to be used in the first procedure "would involve such notions as a belief in God, a holy book, and (at least in two cases out of these three) a historic founder" (Staal 1989: 398). Because the Asian traditions lack some of these characteristics - Buddhism and Confucianism have "a founder, but neither a belief in God nor a holy book", Taoism a founder and a holy book but no belief in God-Staal concludes that "none of the so-called religions of Asia is a religion in this sense .... [A] ny notion of religion that is based upon characteristics of the three Western monotheistic religions is inapplicable in Asia" (Staal 1989: 398). Con-

\footnotetext{
${ }^{12}$ Elsewhere he acknowledges that far from being "its fullest sense" a concept of religion based upon the three Western monotheisms would be "a rather narrow concept of religion" (Staal 1989: 397).
} 
spicuous by its absence in this analysis is any reference to Sikhism, which has all three characteristics. Nevertheless, we can admit Staal's point to a degree, a degree which, once again, amounts to the claim that Asian religions are, in some respects, not like the Western monotheisms.

Staal's argument relies on equating two subtly different concepts that ought to be distinguished from each other. The first is "religion in the Western sense" (Staal 1989: 415, 416), which may be taken to mean what religion is, or what forms it has taken, in the West. Thus, "religion in the Western sense" may be taken to mean that form of monotheistic belief and practice represented by Judaism, Christianity, and Islam. The second is "the Western concept of religion" (Staal 1989: 419), or "Western notions of religion" (Staal 1989: 393), which refers, or ought to refer, to that concept of religion which developed in the West from about the sixteenth century. This concept is not identical to the self-perception of the Western monotheisms. It did emerge in the modern West, but it emerged out of criticism of religion, especially of Christianity. Moreover, the concept has continued to develop, and is no longer, or at least ought no longer to be, dominated by a Protestant Christian emphasis on doctrine or belief. ${ }^{13}$ Thus the modern academic concept of "religion", although Western in origin and perhaps also in use, is not identical to the form $(\mathrm{s})$ that religion has taken in the West. The "Western concept of religion" no longer means only "religions in the Western sense", still less "Western religions". It is clear that Asian religions are in significant respects not "religions in the Western sense", i.e., not monotheistic traditions which place a certain kind of emphasis on doctrinal conformity. Staal has not shown, however, "the inapplicability of Western notions of religion to the traditions of Asia" (Staal 1989: 393), that is, that Asian traditions cannot be understood through a concept of religion that is not modelled on any specific tradition and no longer takes belief to be the all-important feature of religion.

${ }^{13}$ David Chidester lists those who have argued for "an open, multiple, or polythetic definition of religion" (1996: 259). Brian K. Smith has attempted a definition that takes seriously elements of religion which Asian religions have found to be important. He proposes a definition that does not depend on transcendent referents. Religion, he argues, "is defined by its rules of discourse, rules that always (by definition) involve the necessary return to an authoritative source or canon to legitimize all present and past creations, perpetuations, and transformations of that tradition" (1987: 53). 
Staal concludes that "the imposition of the Western concept of religion on the rest of the world illustrates how Western imperialism continues to thrive in the realms of thought" (1989: 419). Ironically, in insisting that Asian traditions are not religions (because they are not religions of the same sort as Christianity and Islam, that is, they are not religions "in the Western sense"), it is Staal who remains enthralled by $a$ Western concept of religion. Insofar as his argument relies on the slippage between "religion in the Western sense" and "the Western concept of religion" it is formally similar to that of Stietencron and Balagangadhara. Staal does acknowledge, however, that this is a "rather narrow" concept of religion and suggests that we might "try to formulate a wider and more flexible concept, and see just where that leads us" (1989: 397). As it has been argued here that this is precisely what in fact has happened during two centuries of academic study of the religions, his argument must be examined, for he concludes that this does not enable us to rescue "religion" as a universal term, and that we ought either to abandon religion or to confine its use to the Western monotheisms.

Staal uses what he calls an "extended-Durkheim" concept of religion, a concept that incorporates the categories of doctrine (belief), ritual, mystical experience, and meditation (the latter either as a fourth category or as a sub-category of one or two of the others') (1989: 401). Of the categories he states that "rites [or rituals] are primary because they are almost always independent and can be accounted for on their own terms ... . Rites become 'religious' when they are provided with a religious interpretation" (1989: 388). Moreover, he states:

Rituals are not merely remarkably persistent within so-called religious traditions, where they are provided with constantly changing interpretations; rituals remain the same even across so-called religious boundaries: they are invariant under religious transformation. This is demonstrated by the fact that the same rites occur in Vedic, Hindu and Buddhist forms, not only in India but also in China, Japan, Tibet, and Indonesia. (Staal 1989: 401)

Staal says little about the other categories, noting only that "[1]ike the other so-called religions of Asia, Buddhism is characterized by the fact that ritual (in which all monks engage) is more important than mystical experience (which only a few attain), which is in turn more important than belief or doctrine (a matter confined to philosophers, scholarly monks or reserved for Western converts, anthropologists, 
and tourists)" (1989: 400). ${ }^{14}$ Thus, for Staal, "the trio of ritual, meditation and mystical experience are more fundamental than the category of religion itself", ritual being the most important of these three in the Asian traditions. But because "rituals remain the same even across so-called religious boundaries" they cannot be used to justify our existing taxonomy of religions. "Only doctrine or belief may be in a position to constitute a religious category per se" (Staal 1989: 401). This lack of correspondence between rituals and beliefs means that if

we adopt the "extended-Durkheim" concept of religion, which incorporates the categories of doctrine (belief), ritual, mystical experience and meditation ... we have a concept on our hands that has all the characteristics of pathological, if not monstrous growth, tumorous with category blunders. It is worse than a spider with a submarine, a burning bush, an expectation and a human head. (Staal 1989:414-415)

Even in Buddhism, "the Asian tradition that is in many respects most religion-like, doctrine plays a subordinate role and mystical experience and rites are basic" (Staal 1989: 415). ${ }^{15}$ Therefore, says Staal, "[w] e must conclude that the concept of religion is not a coherent concept and therefore misleading. It does not hang together like a concept should and should either be abandoned or confined to Western traditions" (1989: 415).

Attention to ritual, rather than belief, as a defining feature of religion may well produce a taxonomy of religions different from the one with which we are familiar, although Staal does not suggest what such a taxonomy based on ritual might look like. Such a taxonomy

${ }^{14}$ He leaves aside the question of "whether meditation constitutes a fourth "fundamental category" " noting only that " $[\mathrm{m}]$ editation, at any rate, is not gazing upon nothing (except in the limiting case), but is closely related to ritual and mantras" (Staal 1989: 400).

${ }^{15}$ Staal concedes that a "phenomenon more like religion in the Western sense appears in the later phases of development of several Asian traditions" (1989: 415). By this he means the development of Śaivism and Vaiṣnavism and of the Bodhisattva ideal in Buddhism. Because these phenomena are more like "religion in the Western sense", he is prepared also to describe them using "the Western concept of religion". Thus Śaivism and Vaiṣnavism "should perhaps be regarded as the first two indigenous religions of India", for with their appearance "a Hindu is no longer an Indian concerned about what he must do while thinking anything he likes", but becomes, for the first time, "a believer in God equipped with faith and a holy book" (1989: 415). Buddhists finally have belief "not in God but in the Buddha" (1989: 416) and Buddhism is therefore closer to being a religion although it still lacks a single authoritative text. 
may be more useful in understanding the history and function of Asian religion, ${ }^{16}$ but would be neither more nor less a natural taxonomy - given in the nature of things - than one based upon belief.

Staal's proposal raises the question of how we are to describe the "Asian traditions that are generally called religions" (Staal 1989: 405406) if we abandon the concept of "religion" or redefine it to refer specifically to doctrine and confine it to Western traditions. Although at one point he refers to Buddhism as "a ritual-mystical cult" (1989: 406), Staal more often relies on other locutions such as "so-called religions" or "traditions". Thus he speaks of "the so-called religions of Asia" (1989: 398, 400) or "the so-called religions of mankind" (1989: 418). Yoga, Māmāṃsā, Śaivism, Vaiṣnavism, and Buddhism are all referred to as "Asian traditions" or "Indian traditions" (1989: 390, 406, 410, 414, 415). Staal also refers to "so-called religious traditions" (1989: 401), the "Asian traditions that are generally called religions" (1989: 405-406), "what is now called a 'religious' tradition" (1989: 393) and simply "religious traditions" (1989: 387). The difficulty Staal has in escaping some collective term for the phenomena he wishes to discuss is not insignificant, and will be returned to later. Here the point is that "Western traditions" and "non-Western traditions" (Staal 1989: 415) are discussed together in a way that suggests the only difference between them is that Western traditions are concerned with doctrine, and are therefore religious, while non-Western traditions are not. They seem nevertheless to be treated by Staal as members of a class, comparable with each other. In practice, then, Staal replaces "religion" with "tradition", where traditions may be religious or not. A concern with doctrine makes a tradition a religious tradition, a concern with ritual does not.

Staal does not seem to be able to avoid defining religion in relation to doctrine or belief: "Only doctrine or belief may be in a position to constitute a religious category per se" (Staal 1989: 401). While the same lingering influence of Protestant Christian conceptions of religion has been detected in other authors, a fundamentally religious ideal underpins Staal's epistemology at a deeper level. Staal argues that study of Buddhism has proceeded upon the unproven assumption that "Buddhism is a religion, and that there is therefore a certain

\footnotetext{
${ }^{16}$ Although this is not so in every case. As Staal notes, many of the rituals in which Buddhist monks engage are "independent of Buddhism" (1989: 401) and therefore would not be significant in defining a useful taxonomy.
} 
unity to the subject". Because "the concept of religion is not easily applicable to Buddhism ... [t] hat unity is therefore imposed from the outside and a priori ... . For scholarship to be adequate, it should not be based upon such assumptions. Only if we abandon them are we in a position to discover whether, and to what extent, such a unity may in fact exist" (Staal 1989: 410). The idea of such a position, free of all assumptions, from which we can discover whether or not Buddhism is a unified entity is not only illusory, as many Buddhists would surely recognize, but also an essentially religious ideal. An indication that Staal thinks such a position is attainable may be gained from the confidence with which he feels able to distinguish "genuine manifestations" of Buddhism from other "representations of Buddhism by Asian Buddhists" (1989: 402). The ideal of such an understanding of the way things are, unmediated by language (and thus by concepts which have a specific history), is very old, going back in the Western tradition at least to Plato. However, as Jonathan Z. Smith points out, in its more recent forms it is

above all, a modulation of one of the regnant Protestant topoi in which the category of inspiration has been transposed from the text to the experience of the interpreter, the one who is being directly addressed through the text .... As employed by some scholars in religious studies it must be judged a fantastic attempt to transform interpretation into revelation. (J. Z. Smith 1990: 55)

The assumption that ritual is a more fundamental category than religion may lead to the emergence of concepts different from (although comparable to) those we presently use to denote different religions. Nevertheless, the impossibility of occupying a position free of all assumptions means that whatever unity such concepts might represent would no more have a definite ontological status than that represented by the terms with which we denote the collections of beliefs and practices which we call religions. The "unity" of Buddhism does not exist, except in, and for the purposes of, analysis, whether that analysis chooses religion - no longer defined simply as the possession of a god, founder, and text - or ritual as its key.

Staal states that "[ $\mathrm{t}]$ he unities presumed to cover early and late Buddhism, or Indian, or Chinese, and other forms of Buddhism, are functions of the same unproven assumption" (1989: 410) that Buddhism is a religion and thus a unity. Fitzgerald makes a similar point with respect to Ambedkar Buddhists in Maharashtra, Theravāda Buddhists in other parts of South Asia, and Japanese Buddhists, argu- 
ing that each inhabit "a significantly different semantic universe", and that the idea that "these are three different manifestations of one essence", or that "Buddhism is an entity with an essence that can be described and listed with other such entities, the Religions or the world religions, can be described as an essentialist fallacy". While "historical and philosophical links between these different culturally situated institutions" exist,

[i]n the Maharashtrian context, it is extremely difficult to separate out some putative Buddhism from the Buddhist (formerly Mahar) caste and thus from the complex ideology of caste institutions. In the Japanese context, it is difficult to conceive of 'Buddhism' as distinct from other indigenous cultural institutions, or from a dominant system of Japanese values in particular. (Fitzgerald 2000a: 26-27)

Fitzgerald makes the same claim in respect of Hinduism. The "analytical centre of gravity of Hinduism" is fundamentally a conception of ritual order or hierarchy, "and there is a strong case for claiming that it is coterminous with traditional Indian culture and with the caste system as a peculiarly Indian phenomenon" (1990: 102). Even the more universalistic sectarian Hindu movements remain "rooted" in this "ideologically defined context", such that Fitzgerald asks in what sense ISKCON at Bhaktivedanta Manor in southern England is the same religion as ISKCON in California or Bengal: "It seems to be the same question essentially as 'What is Christianity', or any other example of 'a religion', abstracted from a particular sociological context? ... . That these are variants of the same reality is a theological claim, made by sociologically specific groups of people. This claim is part of the object of non-theological observation; it should not be one of its basic assumptions" (1990: 115).

Fitzgerald suggests that the methodological priority ought then to be the study of "one or other or all of these institutions in their actual context" (2000a: 27): "we first have to understand the totality within which such institutions are established. We might then hazard a series of abstractions for comparative purposes, without making the mistake of attributing these abstractions and the meaning we give to them to anybody but ourselves" (1990: 108). Fitzgerald argues that scholars, whose study of Hinduism is guided by the "essentially theological concept" of a religion as an entity transcending particular social groups, "cut across the data in the wrong places" with the result that "[v]irtually everything that sociology has revealed about Hinduism is ignored" (1990: 111; 2000a: 136). 
Fitzgerald reports that in his own study of Ambedkar Buddhism he "found the concept of religion unhelpful and instead ... analyzed it in terms of the concepts ritual, politics and soteriology" (2000a: 121). Ritual is here defined by Fitzgerald to be essentially the same "concept of hierarchical order" he identifies elsewhere as the "analytical centre of gravity" of Hinduism. While elements of the practice of this ritual order - for example, practising untouchability against other untouchable castes or the worship of the Buddha and Ambedkar as though they were Hindu gods - are incompatible with Ambedkar's teaching, they are nevertheless "to some variable degree part of the actual situation and identity of Buddhists" (Fitzgerald 2000a: 130). Ambedkar Buddhists are more clearly demarcated from others who share their ritual practices by their politics, which departs from the traditional legitimation of power mediated by ritual status, and by their soteriology, which, though often reinterpreted as "liberation from inequality and exploitation", has "an important spiritual or transcendental element as well ... pursued through reading Buddhist texts, practicing meditation, and going on retreats" (Fitzgerald 2000b: 5). These three concepts allow greater analytical clarity, Fitzgerald argues, than religion, which covers and therefore obscures the relations between ritual, politics, and soteriology. Religion generates a lack of clarity because it "does not effectively demarcate any nonreligious institutions" (Fitzgerald 2000b: 1; cf. Fitzgerald 2000a: 134135). ${ }^{17}$

The issue is whether or not 'religion' does genuinely pick out a distinctive set of institutions that demarcate it from other institutions or whether we need concepts that can pick out finer distinctions that pervade many or most institutions, such as the ritual, the soteriological, and the political. (Fitzgerald 2000a: 149)

So much, states Fitzgerald, "can be, and is, called religion in India that the term picks out nothing distinctive" (2000a: 149). For the term to be a useful analytical category it must be possible to state "what counts as religion and what counts as non-religion" (2000a: 153). However, as Fitzgerald states elsewhere, when "we talk about a religion ... we are not talking about some real type of object" (1990:

${ }^{17}$ Fitzgerald adds, "nor does it clarify the sense in which Buddhists, Christians, Jainas, Muslims, or Sikhs constitute separate minorities in India", and explains that because religion is used to cover ritual principles centred on caste and hierarchy which are shared by non-Hindu groups in India it conceals the distinctiveness which analysis of them as different soteriologies would reveal. 
109) or essence, but, rather, we are making an abstraction, usually for the purposes of comparison. He is wrong to suggest that such an abstraction is only useful if it is infallibly able to demarcate the religious from the non-religious. ${ }^{18}$ It would only be possible for the concept to allow such precise demarcation, to identify what is religion and what non-religion, if religion were indeed a real object, an essence whose manifestations could be identified.

The claim that religion is such an essence, and that the boundaries between the religious and the non-religious can be drawn with such precision is, as Fitzgerald suggests, a religious or theological claim. ${ }^{19}$ In discussing precisely the same issue of caste observances among different groups in India, Roberto Nobili made the claim, crucial for his theological argument, that "there is a norm by which we can distinguish between social actions and the purely religious" (1971 [1619]: 155). Such a claim has no place in a non-theological study of religion. Again, as Fitzgerald states, when "we talk about a religion ... we are not talking about some real type of object that is only contingently associated with any empirical social group, and which can be studied in its own right"; rather, we are "using an analytical category" (Fitzgerald 1990: 109). ${ }^{20}$ He goes on, however, to state that this analytical category "corresponds to what some religious ideologies proclaim themselves to be" (1990: 109). This is only true if we continue to take a religion to be some kind of substantial entity which exists as a real object somehow transcending particular societies. If, instead, religion is regarded as one of a series of abstractions we might hazard for the purpose of comparison of different societies (without, as Fitzgerald states, making the mistake of attributing the abstraction and the meaning given to it to anyone else), there is no reason to regard "religion" as a theological category with no place in an avow-

${ }^{18}$ Neither can the ritual, political, or soteriological always be precisely demarcated from other categories of analysis. Fitzgerald notes that in Maharashtra "some forms of exchange today are descended from the old balutedari system, which was very much embedded in ritual status" (2000a: 122); thus ritual is to some degree confounded with economics. Likewise, some elements of what Fitzgerald categorizes as soteriology can surely also be analysed as either ritual or politics.

19 Fitzgerald argues that this sense of religion as a substantial entity independent of any particular social group is in fact a theological conception, allied to the idea of God, "who transcends all particular social groups and who offers salvation to all individuals everywhere" (1990: 109).

${ }^{20}$ Cf. McCutcheon's contention that "the category of religion is a conceptual tool and ought not to be confused with an ontological category actually existing in reality" (1997: viii). 
edly non- theological discipline, or to expect the category to be able infallibly to discriminate between religious and non-religious phenomena. To think that because the concept of religion emerged from theological claims about the unity of a religion (or the object of that religion) the concept remains theological is to commit the genetic fallacy. Our usage of it clearly no longer corresponds to what religious ideologies proclaim themselves to be. Fitzgerald argues that if we take the examples of Christianity in Salt Lake City and in Tamil $\mathrm{Nadu}$, the claim "that these are variants of the same reality is a theological claim, made by sociologically specific groups of people. This claim is part of the object of non-theological observation; it should not be one of its basic assumptions" (1990: 115). It is at least as likely that it would be denied on theological grounds that two versions of Christianity (let alone, say, Christianity and Hinduism in Tamil Nadu) were variants of the same reality, where non-theological scholars of religion would want to assert that these were variants of the same reality, not in the sense of being both manifestations of a single essence, but in the sense that both could be understood better by being brought under a single analytical category. That category need not be "religion" but there is no compelling reason why it should not be.

\section{4. "Hinduism" and "what has come to be called Hinduism"}

Donald S. Lopez suggests that "one of the ways that scholars of Hinduism may be distinguished from experts on other religions at the annual meeting of the American Academy of Religion is by their overdeveloped pectoral muscles, grown large from tracing quotation marks in the air whenever they have mentioned 'Hinduism' over the past ten years" (2000: 832). The gesture has several oral analogues, usually of the form "what has come to be called Hinduism", or "what Western scholars have designated by the term Hinduism". What is signified by such gestures and tics is nevertheless usually identical with what the term Hinduism has been taken to signify from its earliest use. ${ }^{21} \mathrm{H}$. H. Wilson, in an essay first published in 1828, notes

\footnotetext{
${ }^{21}$ As Lorenzen notes, "most scholars of Indian religions who have not directly addressed this question - and even several who claim that Hinduism is a modern construction - continue to write about Hinduism as if it in fact existed many centuries earlier" (1999: 631).
} 
that " $[\mathrm{t}]$ he Hindu religion is a term, that has been hitherto employed in a collective sense, to designate a faith and worship of an almost endlessly diversified description" (1846 [1828]: 1). Having drawn attention to the constructed nature of the term, such physical and verbal gestures serve to dissociate the speaker from the processes of selection by which the term's meaning is constituted, while allowing her or him to retain the analytical function for which the term was coined. This procedure threatens to reverse recent advances in our understanding of the proper status of key concepts in the academic study of religion, not only of Hinduism, but of religion itself. Dissociating oneself from the inevitable process of selection that underlies our use of this or any other general term (for example, by referring to "what has come to be called Hinduism"), without specifying an alternative basis for selection, merely perpetuates a confusion between conceptual and ontological categories in the study of religion.

It is clear that whatever conception of Hinduism (or any other religion) emerges from such a process of selection is the result of decisions that are inevitably influenced by the purposes and preconceptions of the analyst. It is not a representation of what Hinduism "really" is. Nor need it aspire to be a mirror image of Hindu selfperception, not least because any such self-perception (and these would be legion, not just in the case of Hinduism) would be equally dependent on a specific set of purposes and preconceptions. The representation of Indian religions, which emerged in the works of European writers between the seventeenth and nineteenth centuries, was the result of just such a decision-making process. The usefulness of such representations will depend upon the extent to which we share their purposes.

What the scholarly vocabulary of religion provides is one of a number of possible ways of cutting across the available data. Provided we remain self-conscious about our use of such a vocabulary, and refrain from postulating entities where we have only abstractions and representations, there is no reason why such a vocabulary should not continue to be used. This is not to say that this is the only, or even the best, way of making a selection of data. The question ought therefore to be: How far is it profitable to analyse Hinduism as a religion? There can be no doubt that at times Vaiṣnavism, Śaivism, and Śaktism, or ritual, politics, and soteriology will be more profitable concepts for analysis. But we should never forget that these also are abstractions, and that they are first of all our abstractions (even if 
they are also shared by Hindus). They may, or may not, pre-exist in the consciousness of those studied, or be taken up later (as was the case with some neo-Hindu groups). The intuitive appropriateness of some of these abstractions is of course the result of our preconception of religion, but despite its emergence in the modern West this ought no longer to be dominated by the idea of Christianity as the paradigm of what a religion is. That the modern academic concept of religion emerged in the West does not by itself mean that the concept is inapplicable in other cultures, any more than it means that religion did not exist in the West prior to the articulation of the modern sense of religion. ${ }^{22}$

Having reviewed the history of their production and reproduction as contested terms, David Chidester states that "we might happily abandon religion and religions as terms of analysis if we were not, as a result of that very history, stuck with them. They adhere to our attempts to think about identity and difference in the world" (1996: 259). The recovery of that history in the work of several writers means that these terms can no longer be used innocently. Precisely because it ought now to be impossible to use concepts such as "religion" and "Hinduism" without being aware that in doing so one is applying a theoretical framework to the world, the use of such terms is less likely to result in the unconscious imposition of such a framework than the use of some new coinage, whose theory-laden status may initially be obscured by its novelty. Catherine Bell writes: "That we construct 'religion' and 'science' [and, one might add, 'Hinduism'] is not the main problem; that we forget we have constructed them in our own image - that is a problem" (1996: 188). If so, then not only is there no reason to abandon the terms "religion" and "Hinduism", but there is good reason to retain them.

\section{Department of Religious Studies \\ University of Newcastle \\ Newcastle upon Tyne NE1 7RU \\ United Kingdom}

${ }^{22}$ Note Ninian Smart's comment that " $\left.\mathrm{t}\right]$ he non-traditional nature of western terms does not by itself mean that there is a distorting reification. 'Gamesmanship' is of fairly recent coinage, but gamesmanship preceded the coinage (hence the success of the coinage)" (1974: 46) 


\section{References}

Almond, Philip C. (1996). The heathen in his blindness? Cultural Dynamics 8: 137-145. Balagangadhara, S. N. (1994). "The Heathen in His Blindness ...": Asia, the West and the Dynamic of Religion. Leiden: Brill.

Bell, Catherine (1996). Modernism and postmodernism in the study of religions. Religious Studies Review 22: 179-190.

Bossy, John (1982). Some elementary forms of Durkheim. Past and Present 95: 3-18.

Chidester, David (1996). Savage Systems: Colonialism and Comparative Religion in Southern Africa. Studies in Religion and Culture. London: University Press of Virginia.

Dandekar, R. N. (1971). Hinduism. In C. Jouco Bleeker and Geo Widengren (eds), Historia Religionum: Handbook for the History of Religions, vol. 2: Religions of the Present, 237- 243. Leiden: Brill.

Dalmia, Vasudha and Heinrich von Stietencron (1995). Introduction. In Vasudha Dalmia and Heinrich von Stietencron (eds), Representing Hinduism: The Construction of Religious Traditions and National Identity, 17-32. London: Sage.

Dhareshwar, Vivek (1996). The trial of pagans. Cultural Dynamics 8: 119-135.

Fitzgerald, Timothy (1990). Hinduism and the "world religion" fallacy. Religion 20: 108-118.

- (1997). A critique of "religion" as a cross-cultural category. Method $\&$ Theory in the Study of Religion 9: 91-110.

- (2000a). The Ideology of Religious Studies. Oxford: Oxford University Press.

- (2000b). Problems with "Religion" As A Category for Understanding Hinduism. Decatur, Illinois: Millikin University and International Institute of Indian Studies.

Frykenberg, Robert E. (1997). The emergence of modern "Hinduism" as a concept and an institution: A reappraisal with special reference to South India. In Günther-Dietz Sontheimer and Hermann Kulke (eds), Hinduism Reconsidered, 82107. Delhi: Manohar.

Hardy, Friedhelm (1990). Turning points in the study of Indian religions: 7. Hinduism. In Ursula King (ed.), Turning Points in Religious Studies: Essays in Honour of Geoffrey Parrinder, 145-155. Edinburgh: T. \& T. Clark.

Larson, Gerald James (1995). India's Agony Over Religion. Albany: State University of New York Press.

Lawson E. Thomas and Robert N. McCauley (1990). Rethinking Religion: Connecting Cognition and Culture. Cambridge: Cambridge University Press.

Lipner, Julius J. (1994). The Hindus: Their Religious Beliefs and Practices. London: Routledge.

- (1996). Ancient Banyan: An inquiry into the meaning of "Hinduness". Religious Studies 32: 109-126.

Lopez, Donald S. (2000). Pandit's revenge. Fournal of the American Academy of Religion 68: 831-835.

Lorenzen, David N. (1999). Who invented Hinduism? Comparative Studies in Society and History 41: 630-659.

Loy, David (1996). "... While the scholar in his wisdom bows down to the truth". Cultural Dynamics 8: 147-160.

Marshall, John (1927). Fohn Marshall in India. Notes and Observations in Bengal, 16681672. Sharfaat Ahmed Khan (ed.). London: H. Milford for the Oxford University Press.

McCutcheon, Russell T. (1997). Manufacturing Religion: The Discourse of Sui Generis Religion and the Politics of Nostalgia. Oxford: Oxford University Press. 
Nobili, Roberto (1971 [1619]). Narratio Fundamentorum quibus Madurensis Missionis Institutum caeptum est et hucusque consisit. S. Rajamanickam (ed.) and J. Pujo (trans.) as Adaptation. Palayamkottai: De Nobili Research Institute.

Oberoi, Harjot (1994). The Construction of Religious Boundaries: Culture, Identity, and Diversity in the Sikh Tradition. Chicago: University of Chicago Press.

O'Connell, Joseph (1973). The word "Hindu" in Gauḍiya Vaiṣnava texts. Fournal of the American Oriental Society 93: 340-344.

Preus, J. Samuel (1987). Explaining Religion: Criticism and Theory from Bodin to Freud. New Haven: Yale University Press.

Pye, Michael (1992). An Asian starting point for the study of religion. In Miroslaw Nowaczyk and Zbigniew Stachowski (eds), Language-Religion-Culture: In Memory of Professor Witold Tyloch, 27-35. Warsaw: Polish Society for the Study of Religions/International Association for the History of Religions.

- (2003). Modern Japan and the science of religions. Method E Theory in the Study of Religion 15: 1-27

Sharma, Arvind (2002). On Hindu, Hindustān, Hinduism and Hindutva. Numen 49: $1-36$.

Smart, Ninian (1974). Truth and religions. In John Hick (ed.), Truth and Dialogue:T the Relationship Between World Religions, 45-58. London: Sheldon.

Smith, Brian K. (1987). Exorcising the transcendent: Strategies for defining Hinduism and Buddhism. History of Religions 27: 32-55.

Smith, Jonathan Z. (1990). Drudgery Divine: On the Comparison of Early Christianities and the Religions of Late Antiquity. Chicago: University of Chicago Press.

Smith, Wilfred Cantwell (1991 [1962]). The Meaning and End of Religion: A Revolutionary Approach to the Great Religious Traditions. Minneapolis: Fortress.

Staal, Frits (1982). The Himalayas and the fall of religion. In Deborah E. KlimbergSalter (ed.), The Silk Route and the Diamond Path: Esoteric Buddhist Art on the TransHimalayan Trade Routes, 38-51. Los Angeles: UCLA Art Council.

- (1989). Rules Without Meaning: Ritual, Mantra, and the Human Sciences. New York: Peter Lang.

Stietencron, Heinrich von (1988). Voraussetzungen westlicher Hinduismusforschung und ihre Folgen. In Eberhard Müller (ed.), "... aus der anmuthigen Gelehrsamkeit”, 123-153. Tübinger Studien zum 18. Jahrhundert. Dietrich Geyer zum 60. Geburtstag. Tübingen: Attempto.

- (1995). Religious configurations in pre-Muslim India and the modern concept of Hinduism. In Vasudha Dalmia and Heinrich von Stietencron (eds), Representing Hinduism: The Construction of Religious Traditions and National Identity, 51-81. London: Sage.

- (1997). Hinduism: On the proper use of a deceptive term. In Günther-Dietz Sontheimer and Hermann Kulke (eds), Hinduism Reconsidered, 32-53. Delhi: Manohar.

Sweetman, Will. (2001). Unity and plurality: Hinduism and the religions of India in early European scholarship. Religion 31: 209-224.

Wagle, N. K. (1997). Hindu-Muslim interactions in medieval Maharashtra. In Günther-Dietz Sontheimer and Hermann Kulke (eds), Hinduism Reconsidered, 134-152. Delhi: Manohar.

Wilson, Horace Hayman (1846 [1828]). Sketch of the Religious Sects of the Hindus. Calcutta: Bishop's College Press. 